\title{
Teachers Perception, Usage of Community Resources in Social Studies and Civic Education, Delta State, Nigeria
}

\author{
Onamrewho Favour Atubi \\ Department of Social Science Education Delta State University, Abraka, Nigeria \\ Corresponding Author e-mail: ofatubi@delsu.edu.ng
}

Received: March 2021; Revised: May 2021; Published: July 2021

\begin{abstract}
The study aimed at reporting the perception and usage of community resources by Social Studies and Civic Education teachers in Delta State, South South, Nigeria. Two research questions and one hypothesis were raised to give the study a direction. A sample of 196 out of a population of 656 Social Studies and Civic Education teachers was used for this study. Instrumentation was done with researcher's designed questionnaire with a reliability index of 0.89 . Data was analyzed with percentage for research questions and Analysis of Variance (ANOVA) was used to test the hypothesis of the study. Findings of the study demonstrated that Social Studies and Civic Education teachers of public schools in Delta State perceive the use of community resources to be high for effective teaching but usage of the resources was relatively low. Hence the study concluded by recommending that spirited effort be made by all the stakeholders involved to employ the judicious use of community resources for Social Studies and Civic Education instructions in secondary schools of Delta State.
\end{abstract}

Keywords: Civic Education; Community Resources; Perception; Social Studies and Usage

How to Cite: Atubi, O. F. (2021). Teachers Perception, Usage of Community Resources in Social Studies and Civic Education, Delta State, Nigeria. Jurnal Penelitian Dan Pengkajian Ilmu Pendidikan: ESaintika, 5(2), 118-126. https:// doi.org/10.36312/esaintika.v5i2.429

https:// doi.org/10.36312/esaintika.v5i2.429

Copyright@ 2021, Atubi This is an open-access article under the CC-BY-SA License.

\section{INTRODUCTION}

In the process of teaching Social Studies and Civic Education, it has been noticed that students find it difficult understanding the abstract nature of concepts taught in these subjects (Atubi \& Ogheneakoke, 2020; Obro, 2021). One of the major problems is because teachers have continually used the same traditional methods in teaching Social Studies and Civic education, using the same resources textbook and chalkboard. Furthermore, Ekpenyong, Edem and Martins (2015) observed that the interest of students in Social Studies is decreasing this they attributed to the use of narration approach rather than the use of interactive learning methods and resources like those presented by community resources. That is why; there is a need to consider the adoption of resources such as those found in communities for teaching these subjects as they are community and environmental based subjects. Besides, teaching skills and methods have gone beyond the acts of transmitting knowledge, skills and concepts from teachers to students, to influencing students centered learning through personal observations and experiences like those presented by community resources. The use of community resources will not only provide solutions to problems of 
understanding these subjects but will also motivate and contribute to high learning outcomes of the learners (Atubi 2019).

Consequently, the value and quality of instructions using community resources depend to a large extent on the qualification of teachers; because the educational level of a country cannot rise above the level of education or standard of its teachers. Nwanekezi and Ibekwe (2017) expressed the significance of teachers' qualification and experience in the curriculum implementation of school subjects like Social Studies and Civic Education. The role of teachers as pilots, facilitators and creators when it comes to selecting and using community resources can never be contended. Teachers perceptions, experience and qualification are important in order for them to be able to change the educational experiences of learners through moving beyond the classroom walls to community resources. This will help in diversifying the learning opportunities of students and connect lessons to daily life (Abdulraheem \& Amali 2013). Ajayi (2009) established that there is a nexus between qualification and professional skills. Ibagere (2019) opined that experienced and qualified teachers are more capable of using appropriate teaching methods such as the use of community resources to teach related topics Social Studies and Civic Education.

Community resources are those persons, places and institutions which are suitable in enriching the teaching and learning of subjects like Social Studies and Civic Education (Mezieobi, Fubara \& Mezieobi 2013), they help deepen the content and widen the horizon of learners in the subject matter. Community Resources are found within the community, state or country where the school is located, they can be exploited and utilize to promote the understanding of concepts during teaching and learning of relevant subjects. Examples of community resources are bountiful in every society, they include; educational, social, cultural, economic, religious, historical and administrative resources such as universities, rivers, railways, markets, airports, banks, police stations, parliaments, industries, arts and museum galleries and so much more. Resource persons/professionals can also be brought to the Social Studies and Civic Education class to present professional information on the topic under discussion.

The use of community resources is very appropriate for the effective teaching of Social Studies and Civic Education (Parua, 2018). Atubi (2019) identified six influences of art galleries, museum galleries, banking institutions, traditional institutions, planning sessions and industries. Ikwumelu (2019), posited that communities are like workshops where Social Studies and Civic Education teachers and students can gain firsthand knowledge and experience about the environment, government, institutions, industries and professions. The usage of community resources in teaching cultural and environmental based subjects like Social Studies and Civic Education has become imperative since the school and the community which it is located are intertwine. In regards to appropriate use of instructional methods and resources, such as community resources, the Social Studies and Civic Education teacher's perception must be put into consideration, because this will determine their usage of community resources. Hence this study explores the perception and usage of community resources by Social Studies and Civic Education teachers in Delta State.

Social Studies and Civic Education teachers need to prepare citizens who can survive in a society that is distressed with cultural, environmental and social problems. The use of community resources in teaching and learning these subjects by the teachers holds expectations for reducing these cultural, environmental and social 
problems, at the same time enhancing students' future involvements in the political, social and environmental life of their communities. Parua (2019) measured the attitude and disposition of secondary school Social Studies teachers towards community resources; results signify that the perception of more experienced and qualified teachers was better than less experienced and qualified teachers. Ajala and Ojo (2018) studied teachers' perception on the use of community resources for basic technology instruction and discovered that both male and female basic technology teachers affirmed to their usefulness in teaching basic technology hence the same gesture can be extended to community based subjects like Social Studies and Civic Education.

Atubi (2018) also examined the role of teachers in the selection and usage of community resources and demonstrated that Social Studies teachers should take the lead in using community resources. The teacher is the class pilot, hence his/her perception and usage of community resources cannot be undermined hence this study is significant. As a pilot and facilitator, the teacher occupies a crucial position in the intellectual utilization of the resources in the community. Consequently, if the teacher's perception on the contribution of community resources to knowledge is poor then the teacher is likely not to employ them. On the other hand, if the teacher perceives community resources to be rich with cultural heritage, citizenship engagement, social and environmental experiences. Then the Social Studies and Civic Education teacher will take good advantage of the learning opportunities the present to build students understanding of concepts, their immediate and remote environment. Thereby preparing students to become eminent members of their community/society and contributing to the development and transformation of the Nigerian society.

Furthermore, Social Science Space (2017) asserted that an extensive form of education introduced to the child through the medium of community resources can help to manipulate the educational atmosphere. Usulor (2014) opined that the resources found in every community are effective in implementing the curriculum of both Social Studies and Civic Education of Nigerian secondary schools. Amuzu (2018) raised questions on teachers' extent in using community resources for teaching Social Studies in basic schools of West Mamprusi district in Northern Ghana and discovered that teachers do not engage community resources in teaching Social Studies, this the teachers attributed to time consumption and difficulty in identifying and obtaining community resources.

Tuba (2013) explained that learning outside the classroom can help students to interpret and understands society better thereby concretizing learning. Edinyang \& Effiom (2017) examined the usage of teaching resources in the 21st century and identified community resources as one of them. Thus this research study is an effort to portray the perception and usage of community resources of Social Studies and Civic Education teachers, so as to encourage their utilization in the enhancement of the teaching and learning of Social Studies and Civic Education in Nigeria.

To give a theoretical foundation to the study, the study was hinged on Donald Schon theory of reflection and professional development. This theory explains that by using reflection, professionals will be able to perceive denotative and concealed knowledge through learning from personal observation, this cognition is the basis of what professionals normally do in their various profession. The implication of this theory for the study is that it can help Social Studies and Civic Education teachers to become experts at what they do, when they reflect and perceive the usage of 
community resources in their profession to be high and see the hidden knowledge it can contribute to learning outcomes.

Research Questions 1: What is the perception of Social Studies and Civic Education teachers on the use of community resources in teaching Social Studies and Civic Education in Delta State?

Research Questions 2: What is the level of Social Studies and Civic Education teachers' usage of community resources in teaching of Social Studies and Civic Education in Delta State?

Hypothesis: There is no significant difference in the perception of teachers with different educational qualification on the usage of community resources in the teaching of Social Studies and Civic Education in Delta State?

\section{METHOD}

Explanatory survey research method was adopted for the study, this research method was used because the study seek answer the "why" question. According to DeCarlo (2020) Explanatory research want to know why phenomenon work the way they do. The population consisted of 656 Social Studies and Civic Education teachers of all government owned secondary schools in Delta State. Teachers from private schools were exempted from the study because they hardly stay long in their teaching jobs due to poor remuneration. Multi stage sampling technique was used to select a total of one hundred and ninety-six (196) teachers of both subjects from thirty (30) secondary schools in the three senatorial zones of the state. All schools are similar in teachers' characteristics and population because they are all controlled by the state's ministry of education. The teachers were of male and female sex, they hold NCE, B.Sc, M.Sc(Ed) and a few had Ph.D qualifications. The researcher visited the schools with the help of two assistants; they personally and politely approached the respondents and administered the questionnaires directly to the teachers after explaining the purpose of the research to them. They waited for the questionnaires to be filled and collected same on the spot. Data was collected with a two-part questionnaire to gather the data for the study. Part one collected information on teachers' qualification, while part two contained twenty items designed to extract responses on usage of community resources. Ten items were used to define the perception of teachers, while ten items were used to test the level of community resources usage. The reliability coefficient of the instrument obtained with cronbach alpha was 0.89 , showing that the instrument was reliable. Approval of respondents was sought before administering the instrument; participants' responses were based on a 2 point likert scale of agree or disagree answer. Simple percentage was used to analyze research questions while ANOVA was used to test the research hypothesis at 0.05 level of significance.

\section{RESULTS AND DISCUSSION Presentation and Analysis of Results}

Research Question I: What is the perception of Social Studies and civic education teachers on the use of community resources in teaching Social Studies and Civic Education in Delta State?

Table 1 shows that the responses of Social Studies and Civic Education teachers on item 1-9 is above 50\% (agree) score, this means that they responded positively to item 1-9, while item 10 scored below $50 \%$ (disagree), this goes to show that more than half of the teachers disagree on this item. 
Table 1. Response on Social Studies/civic education teachers on perception of community resources for teaching Social Studies and civic education $(n=196)$

\begin{tabular}{llllll}
\hline S/N & Item & Agree & $\%$ & Disagree & $\%$ \\
\hline 1 & $\begin{array}{l}\text { Community resources enhances the } \\
\text { teaching of Social Studies/Civic }\end{array}$ & 100 & 0 & 0 \\
2 & $\begin{array}{l}\text { Education } \\
\text { Community resources will make the } \\
\text { teaching of Social Studies/civic } \\
\text { education effective } \\
\text { The use of community resources will }\end{array}$ & 196 & 100 & 0 & 0 \\
promote cultural, environmental and \\
national concepts in Social Studies and \\
civic education
\end{tabular}

Source: Fieldwork (2020)

Research Question 2: What is the level of Social Studies and Civic Education teachers' usage of community resources in teaching of Social Studies and Civic Education in Delta State?

Table 2 shows that the responses of Social Studies and Civic Education teachers on item 1-10 score below 50\% (agree) and above 50\% (disagree); this means that all items recorded negative responses from the respondents.

Table 2. Response on Social Studies/Civic Education teachers on usage of community resources for teaching Social Studies and civic education $(n=196)$

\begin{tabular}{llllll}
\hline S/N & Item & Agree & $\%$ & Disagree & $\%$ \\
\hline 1 & $\begin{array}{l}\text { I usually embark on community resources } \\
\text { visit with my student }\end{array}$ & 93 & 47.4 & 103 & 52.6 \\
2 & $\begin{array}{l}\text { I have visited arts/museum galleries with } \\
\text { my students }\end{array}$ & 6 & 3.1 & 190 & 96.9 \\
3 & $\begin{array}{l}\text { I have visited a government institution } \\
\text { with my students before }\end{array}$ & 54 & 27.6 & 142 & 72.4 \\
\hline
\end{tabular}




\begin{tabular}{|c|c|c|c|c|c|}
\hline S/N & Item & Agree & $\%$ & Disagree & $\%$ \\
\hline 4 & $\begin{array}{l}\text { I have visited the palace of a traditional } \\
\text { ruler with my students }\end{array}$ & 83 & 42.3 & 113 & 57.7 \\
\hline 5 & $\begin{array}{l}\text { I have visited a bank or industry with my } \\
\text { student before }\end{array}$ & 28 & 14.3 & 168 & 85.7 \\
\hline 6 & $\begin{array}{l}\text { I have visited the Delta State House of } \\
\text { Assembly with my students }\end{array}$ & 20 & 10.2 & 176 & 89.8 \\
\hline 7 & $\begin{array}{l}\text { There is a school bus in my school that can } \\
\text { be used for community visits }\end{array}$ & 4 & 2 & 192 & 98 \\
\hline 8 & $\begin{array}{l}\text { The school always make financial } \\
\text { provision for fieldtrip/community } \\
\text { resource visits }\end{array}$ & 12 & 6 & 184 & 94 \\
\hline 9 & $\begin{array}{l}\text { Students in my school are made to pay for } \\
\text { community visits }\end{array}$ & 186 & 94.9 & 10 & 5.1 \\
\hline 10 & $\begin{array}{l}\text { I will rate my usage of community } \\
\text { resources as average }\end{array}$ & 92 & 46.9 & 104 & 53.1 \\
\hline
\end{tabular}

Source: Fieldwork (2020)

Hypothesis: There is no significant difference in the perception of teachers with different educational qualification on the usage of community resources in the teaching of Social Studies and Civic Education

Result from Table 3, revealed that the table value of $F$ is .911 and calculated value is .178 at 0.05 level of significance. Since the table value is greater than calculated value, the null hypothesis is accepted.

Table 3. Summary of ANOVA Analysis of teachers with different educational qualifications on the usage and perception of community resources on the teaching of Social Studies and Civic Education

\begin{tabular}{llllllll}
\hline Source of variance & $\begin{array}{l}\text { Sum of } \\
\text { Squares }\end{array}$ & Df & $\begin{array}{l}\text { Mean } \\
\text { square }\end{array}$ & F-Cal. & F.Tab. & LS & Decision \\
\hline Between Groups & .113 & 3 & .038 & .178 & .911 & 0.05 & $\begin{array}{l}\text { Accept } \\
\text { Ho }\end{array}$ \\
Within Groups & 40.723 & 192 & .212 & & & & \\
Total & 40.837 & 195 & & & & & \\
\hline
\end{tabular}

Source: Fieldwork (2020)

\section{Discussion}

The result of the study as shown in Table 1, answered research question one, items 1-3 shows that $100 \%$ of Social Studies and Civic Education teachers agree that community resources enhances the teaching of Social Studies and Civic Education, promote cultural, environmental and national concepts as well as make the teaching of the subjects effective. Similarly, $78.5 \%$ of teachers agree that community resources enhance student's future involvement in social and political issues, $81.6 \%$ agree that it provides an extensive form of education and78\% agree that it help students to understand their community better. Consequently $84.2 \%$ see community resources as teaching resources of the 21 st century, $85.2 \%$ agrees it promote students centered learning. Nevertheless, a whopping $82.2 \%$ believe that making use of community resources consumes time and resources, also $47 \%$ perceive that only more experienced and highly qualified teachers can make use of community resources as against $53 \%$ who think otherwise. These findings have a nexus with those of Social Science Space 
(2017); Tuba (2013); Ajala and Ojo (2018); and Atubi (2019). These studies pointed out the importance of community resources by promoting and enhancing the effective teaching of Social Studies and by extension civic education, in addition they also promote cultural, environmental and national concepts.

Findings/results to research question 2 revealed that $52.6 \%$ Social Studies and Civic Education teachers acknowledged that they don't make use of community resources, while $47.4 \%$ admitted that they had made use of community resources at some point in time. Also 96.9\% conceded that they had never visited an art/museum gallery before as against $6 \%, 72.4 \%$ have never visited any government institution with their students and $85.7 \%$ have never visited a bank now industry. However, $57.7 \%$ have not visited any traditional institution, $89.8 \%$ have not taken a trip to House of Assembly and $98 \%$ of the schools whose teachers were used for the study don't have a school bus that can be used for visiting community resources. Equally, only $6 \%$ of schools can make financial provision for community visit while $94 \%$ don't have the financial resources to do that, while $46.9 \%$ of teachers rated their usage of community resources as average. These findings are in agreement with Amuzu (2018) and Usulor (2014) which lamented the non-usage of community resources by Social Studies teachers in Ebonyi State, Nigeria and West Mamprusi District of Northern Ghana region.

The result of hypothesis explicitly shows that there was no significant difference among the perception of Social Studies and Civic Education teacher with different educational qualification on the usage of community resources in teaching Social Studies and Civic Education as the table value of F (.911) was greater than the calculated value of $\mathrm{F}(.178)$ at 0.05 level of significance. These findings are in harmony with Ajayi (2009); Nwanekezi and Ibekwe (2017); and Ibagare (2019) who established that teacher's qualification is pivotal to usage of innovative teaching techniques like community resources usage. But the findings are in disharmony with the study of Parua (2019), who measured that attitude of teachers towards the use of community resources and discovered that the perception of more experienced and qualified teachers was better than that of less experienced and less qualified teachers. This finding also have a connection with Donald Schon theory of reflection and professional development because the theory emphasized that teachers can become specialist in their field when they reflect and perceived concealed knowledge. This implies that it is the perception of Social Studies and Civic education teachers as reported in the findings that will determine their usage of community resources in teaching. These findings are in congruence with other studies like (Dada, 2013; Tuba, 2013; Usulor, 2019 \& Atubi, 2019).

\section{CONCLUSION}

Arising from the findings and results of this study, there is evidence that Social Studies and Civic Education teachers in Delta State perceive the use of community resources in teaching the Social Studies and Civic Education to be effective. Secondly, the usage of community resources by Social Studies and Civic Education teachers in Delta State, Nigeria is low.

\section{RECOMMENDATION}

The researcher therefore recommend that spirited effort should be made by all stakeholders among whom are Social Studies and Civic Education teachers, school 
administrators, students, parents and government in employing the judicious use of community resources to make learning of Social Studies and Civic Education more real, concrete and meaningful for student.

\section{ACKNOWLEDGMENT}

The author would like to acknowledge all the teachers who participated in this study, without whom the study wouldn't have been possible. The author would also like to thank the head of department social sciences education department who gave approval for the study and also the authors whose works were cited in this article.

\section{REFERENCES}

Abdulraheem, Y. \& Amali, I., O., O. (2013). Teachers pedagogical skills and use of instructional materials as correlate of student performance in Social Studies. 'Revve International delangues Traduction et d'interpretariat' (RILTRI), 1(1):2-15.

Ajayi, P.O. (2009) Effective teaching of physics. A paper presented at a seminar on effective teaching of sciences in Ekiti State organised by Ekiti state Ministry of Science and Technology, Ado-Ekiti

Ajala, I., R. \& Ojo, O., A. (2018). Teachers perception of community resources utilization for sustainability of basic technology instructions in South West Nigeria. International Journal of Education and Evaluation, 4(7): 16-25, ISSN 24890073.

Amuzui, S. (2018). Bridging the gap between theory and practice: Teacher's utilization of instructional resources in teaching Social Studies in basic schools in West Mamprusi district, Northern region, Ghana. International Journal of Education, Learning and Development (IJELD), 6(1):10-25.

Atubi, O., F. (2018). The role of teachers, guidelines, principles and criteria in selecting community resources for Social Studies education in secondary schools of Delta State. Journal of Educational Horizon, 12(10):175-179.

Atubi, O., F. (2019). Teacher utilization of community resources and effective teaching of upper basic Social Studies students in Delta State. Unpublished M.sc. Dissertation, Delta State University, Abraka, Nigeria.

Atubi, O., F \& Ogheneakoke, O.,C. (2020).Approaches to Citizenship Education for National Unity in Nigeria.African Journal of Studies in Education 15 (1), 85-96.

Dada, S., O. (2013). Utilization of community resources for effective sustainability of Social Studies education. International Journal of Science and Research (IJSR),2(6):466-469.

DeCarlo, M. (2020). Types of research. Press Books. work.pressbook.com

Edinyana, S., D. \& Effiom, N.V. (2017). Social Studies teaching resources in the $21^{\text {st }}$ century. International Journal of Sociology and Anthropology Research (IJSAR), 3(4):8-14

Ekpenyons, E.E., Edem, A.O. \& Martin, O.I. (2015). Students interest in Social Studies and academic achievement in tertiary institutions in Cross River State Nigeria. European Journal of Training and Development Studies, 2(2), 35-40.

Ibagere, M.K. (2019) School type, teacher qualification, experience and academic performance of Upper Basic Social Studies students in Delta State (An unpublished M.Sc. Dissertation submitted to the postgraduate school, DELSU).

Ikwumelu, S.,N. (2019). Social Studies Education in Nigeria. Onitsha, Nigeria: Outrite publishers. 
Mezieobi, K.,A. Fubara, V., R. \& Mezieobi, S., A. (2013). Teaching methods, instructional materials and resources. Owerri, Nigeria: Acada Pek publishers.

Obro, S. (2021). The Internet and Quality Social Studies Education for Sustainable Development in Post-Covid-19: a Review. Jurnal Penelitian dan Pengkajian Ilmu Pendidikan: e-Saintika 5 (1), 15-26,

Parua, R., K. (2019). Attitude of secondary school teachers towards using community resources in Social Studies education. International Journal of Research and Analytical Review (IJRAR) 5(3): 23-25.

Schon, D. (2012). The reflective practitioner. Gray's Research Reading Group. Online at

https;//www.google.com/amp/s/grayreadinggroup.wordpress.com/2012/ $12 / 18 /$ the- reflective-practition...

Social Science Space (2017). Community resources for teaching Social Studies in the school education. Retrieved from jagindhere.word.press.com

Tuba, C. (2013). Social Studies teachers' views on learning outside the classroom, educational consultancy and research centre. Retrieved from www.edam.com.trlestp

Usulor, V., I. (2014). Utilization of resources for effective implementation of Social Studies curriculum in junior secondary schools of Ebony central education zone. Unpublished M.sc. Dissertation, University of Nigeria, Nsukka. 